\title{
Pollen analysis of honey and pollen collected by Apis mellifera linnaeus, 1758 (Hymenoptera, Apidae), in a mixed environment of Eucalyptus plantation and native cerrado in Southeastern Brazil
}

\author{
C. M. G. Simeão ${ }^{a, b}$, F. A. Silveira ${ }^{a}$, I. B. M. Sampaio and E. M. A. F. Bastos $^{b^{*}}$ \\ aDepartamento de Zoologia, Instituto de Ciências Biológicas, Universidade Federal de Minas Gerais - UFMG, \\ Av. Presidente Antônio Carlos, 6627, Pampulha, CEP 31270-901, Belo Horizonte, MG, Brazil \\ bLaboratório de Palinologia, Serviço de Recursos Vegetais e Opoterápicos, Diretoria de Pesquisa e Desenvolvimento, \\ Fundação Ezequiel Dias, Rua Conde Pereira Carneiro, 80, Gameleira, CEP 30510-010, Belo Horizonte, MG, Brazil \\ 'Departamento de Ciência Animal, Escola de Veterinária, Universidade Federal de Minas Gerais - UFMG, \\ Av. Presidente Antônio Carlos, 6627, Pampulha, CEP 31270-901, Belo Horizonte, MG, Brazil \\ *e-mail: embastos@funed.mg.gov.br
}

Received: December 10, 2013 - Accepted: April 9, 2014 - Distributed: February 30, 2015

\begin{abstract}
Eucalyptus plantations are frequently used for the establishment of bee yards. This study was carried on at Fazenda Brejão, northwestern region of the State of Minas Gerais, Brazil. This farm is covered both with native Cerrado vegetation (Brazilian savanna) and eucalyptus plantations. This paper reports on the botanic origin of pollen pellets and honey collected from honeybee (Apis mellifera) hives along a thirteen-month period (January 2004 to January 2005). The most frequent pollen types found in the pollen pellets during the rainy season were Trema micrantha (Ulmaceae), Copaifera langsdorffii (Fabaceae), an unidentified Poaceae, unidentified Asteraceae-2, Cecropia sp. 1 (Cecropiaceae) and Eucalyptus spp. (Myrtaceae); during the dry season the most frequent pollen types were Acosmium dasycarpum (Fabaceae), Cecropia sp. 1 (Cecropiaceae) and Eucalyptus spp. (Myrtaceae). Pollen grains of Baccharis sp. (Asteraceae), Cecropia sp. 1 (Cecropiaceae), Copaifera langsdorffi (Fabaceae), Mimosa nuda (Fabaceae), Eucalyptus spp. (Myrtaceae) and Trema micrantha (Ulmaceae) were present in the honey samples throughout the study period.
\end{abstract}

Keywords: Apis mellifera, Cerrado, pollen, honey, palynology.

\section{Espectro polínico do alimento coletado por Apis mellifera linnaeus, 1758 (hymenoptera, apidae), em ambiente contendo plantações de Eucalyptus e cerrado nativo no sudeste brasileiro}

\begin{abstract}
Resumo
Plantações de Eucalyptus são, frequentemente, utilizadas como locais de instalação para colmeias. Este estudo foi realizado na Fazenda Brejão, localizada no noroeste de Minas Gerais, Brasil. Esta fazenda é coberta por Cerrado nativo (savana brasileira) e por plantações de eucaliptos. Este trabalho indica a origem botânica de bolotas e mel coletados em colmeias de Apis mellifera por um período de 13 meses (Janeiro/2004 a janeiro/2005). Os tipos polínicos mais frequentes nas amostras de pólen durante a estação chuvosa foram Trema micrantha (Ulmaceae), Copaifera langsdorffii (Fabaceae), Poaceae, Asteraceae não identificada 2, Cecropia sp. 1 (Cecropiaceae) e Eucalyptus spp. (Myrtaceae); na estação seca, os tipos polínicos mais frequentes foram Acosmium dasycarpum (Fabaceae), Cecropia sp. 1 (Cecropiaceae) e Eucalyptus spp. (Myrtaceae). As espécies Baccharis sp. (Asteraceae), Cecropia sp. 1 (Cecropiaceae), Copaifera langsdorffi (Fabaceae), Mimosa nuda (Fabaceae), Eucalyptus spp. (Myrtaceae) e Trema micrantha (Ulmaceae) estiveram presentes durante todo o período amostrado.
\end{abstract}

Palavras-chaves: Apis mellifera, Cerrado, pólen, mel, palinologia.

\section{Introduction}

The Cerrado is an important Brazilian ecosystem with diverse phyto-physiognomies such as forest, savanna and field (Brandão, 2000). It is considered one of the 25 biodiversity hotspots in the World (Mittermeier et al., 2000) for its exceptional concentration of endemic species

and experiencing exceptional loss of habitat because of human activities (Silva and Bates, 2002). Currently, only $20 \%$ of its primary vegetation is left and only $1.2 \%$ is protected in conservation units (Mittermeier et al., 2000). Some features of the Cerrado, such as vegetation diversity, 
great richness in nectariferous/pollineferous plants and low density of trees, make this a favorable region for beekeeping (Bastos et al., 2003). According to Carvalho and Bego $(1995,1996)$ and Viana et al. (1997), A. mellifera is one of the most common flower visitors of the Cerrado.

Nowadays, large portions of the Cerrado has been substituted by eucalyptus plantations (generally extensive), with more than $67 \%$ of the planted area concentrated in southeastern Brazil (Bernardo et al., 1998). In the state of Minas Gerais, most of the 1.5 million hectares of planted forest is eucalyptus plantations (Silveira, 2004), of wich the species used for the production of cellulose, wood and charcoal, are considered to be important pollen and nectar sources for the honeybees (Bastos, 1995; Bastos et al., 2003; Melo, 2004). For this reason, beekeepers frequently search for eucalyptus plantations to establish their bee yards.

The identification of plants visited by bees is an important indicator of nectar and pollen sources, permitting beekeepers to optimize the use of trophic resources, especially in natural vegetation (Howes, 1953). It is possible to identify the main melliferous and polleniferous plants exploited by bees in a delimited region through the identification of the pollen types found in the bee products (Barth, 1989).

Pollen grains is the natural source of proteins, lipids, vitamins and mineral salts for bees, being the only source of nitrogenated food available for bee larvae, and its absence may result in the hive extinction (Minckley et al., 2000). As for the energy source bees make use of nectar, transformed into honey (Doner, 1977).

The knowledge of the food sources most employed by bees is important to define strategies to enhance beekeeping productivity and profitability, as well as to certify the good quality and provenance of honeys (Bastos, 1996; Moreti et al., 2000).

Thus, the aim of the present study was to identify the food sources exploited by honeybees colonies established in firebreaks between native Cerrado vegetation and eucalyptus plantations in the northwestern region of Minas Gerais through the palynological analysis of honey samples and pollen pellets collected in honeybee hives.

\section{Material and Methods}

This study was carried out in the Fazenda Brejão, a farm owned by $\mathrm{V} \& \mathrm{M}$ Florestal Ltda. located in the municipality of Brasilândia de Minas ( $17^{\circ} 01^{\prime}$ S ; 45 $52^{\circ}$ 'W), northwestern region of the State of Minas Gerais, Brazil. The native Cerrado vegetation covers $65 \%$ of the 35.899 -ha area of the farm and the remaining 32\% is covered by eucalyptus plantations (Scolforo et al., 2001). The regional climate is the dry-sub humid tropical of Holdridge, with an annual average temperature between $22{ }^{\circ} \mathrm{C}$ and $24{ }^{\circ} \mathrm{C}$, and annual average precipitation between $700 \mathrm{~mm}$ and $1000 \mathrm{~mm}$ (Golfari, 1975). During the study period, the average temperature and precipitation in the region were of $30.7^{\circ} \mathrm{C}$ and $1895 \mathrm{~mm}$, respectively.

Samples of flowering-plant species were collected monthly, between January 2004 and January 2005, along firebreak margins and inside Cerrado reserves. The plants were identified by the staff of the herbarium of the Taxonomic Collections of the Universidade Federal de Minas Gerais (BHCB) and deposited in the Laboratório de Palinologia of the Fundação Ezequiel Dias (FUNED), in Belo Horizonte, Minas Gerais, Brazil. Pollen collected from the anthers of these plants were acetolized according to Erdtman (1960) and used to prepare slides, which were deposited in the FUNED-POL reference slide collection, where pollen of plants previously collected in the Fazenda Brejão were already represented.

Two bee yards were established along firebreaks between eucalyptus plantations and native Cerrado vegetation (Beeyard-1: 17 0' 38" S; 45 51'42" W; altitude: $532 \mathrm{~m}$. Beeyard-2: $17^{\circ} 0$ ' 46” S; 45 49' 31' W; altitude: $551 \mathrm{~m}$ ), each containing three productive colonies housed in Langstroth hives.

\subsection{Obtaining and preparing pollen samples for analysis}

Pollen was collected once a week with the aid of pollen traps placed in the hive entrances for 24 hours, during the 13-month sampling period. These pollen traps extract about $50 \%$ of the pollen loads brought to the colony by the worker bees (Nagamitsu and Inoue, 1999). Pollen pellets collected were transferred to numbered plastic vials, which were hermetically closed and kept in a refrigerator at $4{ }^{\circ} \mathrm{C}$ until use.

Pollen samples from a single colony were weighed, dehydrated, homogenized, crushed, and three aliquots of $0.1 \mathrm{~g}$ were separately acetolized and used to prepare microscopic slides according to Erdtman (1960). These slides were deposited in the FUNED-POL slide collection.

\subsection{Obtaining and preparing honey samples}

Monthly, all frames containing only honey-filled cells (operculated or not) loaded in the past 30-day period were centrifuged (Guerra and Méndez, 2004). The honey obtained was sieved, homogenized and stored in hermetically-closed plastic vials. The pollen contained in each sample was acetolized and mounted in microscopic slides, according to Louveaux et al. (1978).

\subsection{Analysis of pollen and honey samples}

The identification of the pollen grains, in the previously prepared slides, was obtained through morphological analysis under the microscope comparing with pollen descriptions from Erdtman (1952) and Laboriau (1973) and through comparison with the reference slides in the FUNED-POL reference pollen collection. The frequency of each pollen type in 1200 pollen grains counted in each slide was calculated.

Pollen grains identified in the honey samples were grouped in four frequency classes according to the usual proceedings in melissopalynology, as suggested by Louveaux et al. (1970) and Barth (1970a, b, c): predominant pollen (representing more than $45 \%$ of all grains in the sample); accessory pollen (representing between $15 \%$ and $44 \%$ of the grains); isolated pollen (between $3 \%$ and $14 \%$ ) 
and occasional isolated pollen (less than 3\%). Sub and over-representation of specific pollen types were considered in the data interpretation (Barth, 1989).

The contribution of the different pollen types was presented here relative to the two seasons in which the year is clearly divided and which define the management practices in the apiaries: dry (May to October) and rainy (November to April).

\section{Results}

\subsection{Pollen spectrum in pollen pellets}

Sixty-nine pollen types were identified in the 127 samples obtained. They belong to 28 plant families, with Fabaceae accounting for the larger number of species (14) found in the samples (Table 1).

More pollen types were recorded in the dry season (50 types) than in the rainy season (42). During the rainy season, pollen of Eucalyptus represented $8.27 \%$ of all pollen grains observed in the pollen pellets and during the dry season this figure rose to $14.54 \%$.

\subsection{Pollen spectrum of the honey samples}

Twenty-one honey samples were collected during the study. No honey was available in the colonies between March and July 2004 and October 2004 and January 2005, when the populations were in decline.

Forty-eight pollen types were recorded in the honey samples, with Fabaceae and Asteraceae families representing the largest numbers of different plant types (11 and nine, respectively). November was the month with the largest variety of pollen types (30), and February with the smallest (18) (Table 2).

Pollen of Eucalyptus spp. was present during all the sampling period, although never as a predominant type pollen (it was accessory in August and isolated pollen in January, February, September, November and December) (Table 2).

Table 1. Frequency of the pollen types present in pollen pellets samples collected in Fazenda Brejão, in the municipality of Brasilândia de Minas, State of Minas Gerais, Brazil, between January 2004 and January 2005.

\begin{tabular}{|c|c|c|}
\hline \multicolumn{3}{|c|}{ Frequency of each pollen type $(\%)$} \\
\hline Pollen types & $\begin{array}{l}\text { Rainy Season (November-April) } \\
\qquad N=61\end{array}$ & $\begin{array}{c}\text { Dry Season (May-October) } \\
\qquad N=66\end{array}$ \\
\hline \multicolumn{3}{|l|}{ Anacardiaceae } \\
\hline Astronium sp. & 0.00 & 5.26 \\
\hline Schinus sp. & 0.01 & 0.00 \\
\hline Tapirira guianensis & 1.56 & 0.02 \\
\hline \multicolumn{3}{|l|}{ Araliaceae } \\
\hline Schefflera sp. & 0.62 & 0.27 \\
\hline \multicolumn{3}{|l|}{ Asteraceae } \\
\hline Baccharis sp. & 3.45 & 0.58 \\
\hline Echinocoryne holosericea & 0.05 & 0.07 \\
\hline Eremanthus sp. & 0.03 & 0.00 \\
\hline Eupatorium sp. & 2.15 & 2.15 \\
\hline Ichthyothere cunabi & 0.01 & 0.00 \\
\hline Mikania sp. & 3.57 & 0.00 \\
\hline Vernonia sp. & 0.04 & 0.01 \\
\hline Wedelia sp. & 0.05 & 0.00 \\
\hline Asteraceae unidentified 1 & 0.07 & 0.15 \\
\hline Asteraceae unidentified 2 & 14.46 & 0.00 \\
\hline Asteraceae unidentified 3 & 0.00 & 0.03 \\
\hline Asteraceae unidentified 4 & 0.13 & 0.49 \\
\hline \multicolumn{3}{|l|}{ Bignoniaceae } \\
\hline Arrabidaea florida & 0.32 & 0.00 \\
\hline Memora nodosa & 0.02 & 0.00 \\
\hline \multicolumn{3}{|l|}{ Bombacaceae } \\
\hline Eriotheca sp. . & 0.00 & 0.34 \\
\hline \multicolumn{3}{|l|}{ Cecropiaceae } \\
\hline Cecropia sp. 1 & 11.60 & 25.73 \\
\hline Cecropia sp. 2 & 0.41 & 0.01 \\
\hline \multicolumn{3}{|l|}{ Combretaceae } \\
\hline Terminalia sp. & 0.00 & 0.02 \\
\hline
\end{tabular}

$\mathrm{N}=$ number of samples. 
Table 1. Continued...

\begin{tabular}{|c|c|c|}
\hline \multicolumn{3}{|c|}{ Frequency of each pollen type (\%) } \\
\hline Pollen types & $\begin{array}{c}\text { Rainy Season (November-April) } \\
\qquad \mathrm{N}=61\end{array}$ & $\begin{array}{c}\text { Dry Season (May-October) } \\
N=66\end{array}$ \\
\hline \multicolumn{3}{|l|}{ Convolvulaceae } \\
\hline Ipomoea sp. & 0.00 & 0.02 \\
\hline Jacquemontia sp. & 0.00 & 0.02 \\
\hline \multicolumn{3}{|l|}{ Cyperaceae } \\
\hline Cyperaceae unidentified 1 & 0.08 & 0.01 \\
\hline \multicolumn{3}{|l|}{ Dilleniaceae } \\
\hline Davilla elliptica & 0.00 & 3.04 \\
\hline \multicolumn{3}{|l|}{ Fabaceae } \\
\hline Acosmium dasycarpum & 0.00 & 34.79 \\
\hline Bauhinia pulchella & 0.00 & 0.10 \\
\hline Bauhinia sp. & 0.00 & 0.03 \\
\hline Canavalia sp. & 0.01 & 0.00 \\
\hline Clitoria fairchildiana & 0.00 & 0.01 \\
\hline Copaifera langsdorffii & 16.94 & 0.00 \\
\hline Leucaena sp. & 0.00 & 2.14 \\
\hline Mimosa nuda & 0.47 & 0.76 \\
\hline Mimosa sp. & 0.19 & 0.00 \\
\hline Stryphnodendron sp. & 0.00 & 0.03 \\
\hline Stylosanthes scabra & 0.01 & 0.01 \\
\hline Trifolium $\mathrm{sp}$ & 0.00 & 0.07 \\
\hline Fabaceae unidentified 1 & 0.00 & 0.02 \\
\hline Fabaceae unidentified 2 & 0.01 & 0.17 \\
\hline \multicolumn{3}{|l|}{ Lamiaceae } \\
\hline Hyptis sp. & 0.00 & 0.01 \\
\hline \multicolumn{3}{|l|}{ Lecythidaceae } \\
\hline Cariniana sp. & 0.07 & 0.00 \\
\hline \multicolumn{3}{|l|}{ Loganiaceae } \\
\hline Antonia ovata & 0.00 & 0.87 \\
\hline Loganiaceae unidentified 1 & 0.00 & 0.33 \\
\hline \multicolumn{3}{|l|}{ Loranthaceae } \\
\hline Struthanthus flexicaulis & 0.01 & 0.00 \\
\hline \multicolumn{3}{|l|}{ Lythraceae } \\
\hline Lafoensia pacari & 0.00 & 0.01 \\
\hline \multicolumn{3}{|l|}{ Malpighiaceae } \\
\hline Byrsonima coccolobifolia & 0.02 & 0.02 \\
\hline Byrsonima sp. & 0.53 & 0.00 \\
\hline \multicolumn{3}{|l|}{ Malvaceae } \\
\hline Malvastrum sp. & 0.00 & 0.04 \\
\hline Sida linifolia. & 0.03 & 0.00 \\
\hline Sida sp. & 0.02 & 0.02 \\
\hline Malvacea unidentified 1 & 0.01 & 0.00 \\
\hline \multicolumn{3}{|l|}{ Melastomataceae } \\
\hline Rhyncanthera sp. & 0.00 & 0.12 \\
\hline Melastomataceae unidentified 1 & 0.00 & 0.10 \\
\hline Melastomataceae unidentified 2 & 0.00 & 0.02 \\
\hline \multicolumn{3}{|l|}{ Myrtaceae } \\
\hline Eucalyptus sp. & 8.27 & 14.54 \\
\hline Eugenia dysenterica & 0.00 & 1.09 \\
\hline Myrcia sp. & 0.01 & 0.03 \\
\hline
\end{tabular}

Myrcia $\mathrm{sp}$. 
Table 1. Continued...

\begin{tabular}{|c|c|c|}
\hline \multicolumn{3}{|c|}{ Frequency of each pollen type $(\%)$} \\
\hline Pollen types & $\begin{array}{l}\text { Rainy Season (November-April) } \\
\qquad N=61\end{array}$ & $\begin{array}{l}\text { Dry Season (May-October) } \\
\qquad N=66\end{array}$ \\
\hline Myrtaceae unidentified 1 & 0.00 & 0.01 \\
\hline \multicolumn{3}{|l|}{ Onagraceae } \\
\hline Ludwigia sp. & 0.00 & 0.68 \\
\hline \multicolumn{3}{|l|}{ Palmae } \\
\hline Mauritia flexuosa & 0.05 & 0.00 \\
\hline Palmae unidentified 1 & 0.01 & 0.02 \\
\hline \multicolumn{3}{|l|}{ Poaceae } \\
\hline Poacea unidentified 1 & 16.12 & 1.38 \\
\hline \multicolumn{3}{|l|}{ Rubiaceae } \\
\hline Diodia sp. & 0.25 & 0.02 \\
\hline Richardia sp. & 0.01 & 0.00 \\
\hline \multicolumn{3}{|l|}{ Sapindaceae } \\
\hline Serjania sp. & 0.00 & 0.24 \\
\hline \multicolumn{3}{|l|}{ Solanaceae } \\
\hline Solanum sp. & 0.53 & 0.01 \\
\hline \multicolumn{3}{|l|}{ Ulmaceae } \\
\hline Trema micranta & 17.45 & 2.15 \\
\hline \multicolumn{3}{|l|}{ Verbenaceae } \\
\hline Stachytarpheta $\mathrm{sp}$. & 0.01 & 0.00 \\
\hline \multicolumn{3}{|l|}{ Unidentified Families } \\
\hline Unidentified & 0.34 & 1.94 \\
\hline
\end{tabular}

$\mathrm{N}=$ number of samples.

Table 2. Frequency of pollen types present in honey samples collected between January 2004 and December 2004 in Fazenda Brejão, municipality of Brasilândia de Minas, State of Minas Gerais, Brazil.

\begin{tabular}{|c|c|c|c|c|c|c|}
\hline \multirow{3}{*}{ Pollen types } & \multicolumn{6}{|c|}{ Frequency of pollen types (\%) } \\
\hline & Jan/04 & Feb/04 & Aug/04 & Sep/04 & Nov/04 & Dec/04 \\
\hline & $\mathbf{N}=4$ & $\mathbf{N}=\mathbf{4}$ & $\mathbf{N}=\mathbf{2}$ & $\mathbf{N}=\mathbf{2}$ & $\mathbf{N}=7$ & $\mathbf{N}=\mathbf{2}$ \\
\hline \multicolumn{7}{|l|}{ Anacardiaceae } \\
\hline Anacardiaceae unidentified 1 & 0.24 & & & & 4.19 & \\
\hline Astronium sp. & 0.35 & 0.45 & 0.72 & 5.33 & 7.10 & 2.73 \\
\hline Tapirira guianensis & & & 0.36 & & 14.07 & 12.89 \\
\hline \multicolumn{7}{|l|}{ Araliaceae } \\
\hline Schefflera sp. & & 0.23 & 1.27 & & & \\
\hline \multicolumn{7}{|l|}{ Asteraceae } \\
\hline Achyrocline sp. & 0.02 & & & & & \\
\hline Ageratum sp. & & 0.02 & & & & \\
\hline Ayapana sp. & & 0.02 & & & & \\
\hline Baccharis sp. & 17.78 & 14.70 & 8.95 & 3.22 & 0.09 & 3.64 \\
\hline Eremanthus sp. & & 0.02 & & & & \\
\hline Eupatorium sp. & & & 0.81 & & & 1.21 \\
\hline Mikania sp. & & 1.02 & & & & \\
\hline Tagetes sp. & 0.02 & & & & & \\
\hline Vernonia sp. & 0.04 & & 0.27 & & & \\
\hline \multicolumn{7}{|l|}{ Bignoniaceae } \\
\hline Arrabidaea florida & 0.11 & 2.27 & 3.80 & & & \\
\hline Arrabidaea sp. & 0.15 & & & & & \\
\hline \multicolumn{7}{|l|}{ Bombacaceae } \\
\hline Eriotheca sp. & & & 0.18 & 0.10 & & \\
\hline
\end{tabular}

$\mathrm{N}=$ number of samples. 
Table 2. Continued...

\begin{tabular}{|c|c|c|c|c|c|c|}
\hline \multirow{3}{*}{ Pollen types } & \multicolumn{6}{|c|}{ Frequency of pollen types (\%) } \\
\hline & Jan/04 & Feb/04 & Aug/04 & Sep/04 & Nov/04 & Dec/04 \\
\hline & $\mathbf{N}=4$ & $N=4$ & $\mathbf{N}=\mathbf{2}$ & $\mathbf{N}=\mathbf{2}$ & $\mathbf{N}=7$ & $\mathbf{N}=\mathbf{2}$ \\
\hline \multicolumn{7}{|l|}{ Cecropiaceae } \\
\hline Cecropia sp. 1 & 22.89 & 17.59 & 32.91 & 61.62 & 37.35 & 53.01 \\
\hline \multicolumn{7}{|l|}{ Combretaceae } \\
\hline Terminalia sp. & & & 0.27 & 2.62 & 0.44 & \\
\hline \multicolumn{7}{|l|}{ Cyperaceae } \\
\hline Cyperaceae unidentified 1 & & & 0.36 & & 0.05 & \\
\hline \multicolumn{7}{|l|}{ Fabaceae } \\
\hline Acosmium dasycarpum & & & & 14.99 & 11.29 & 2.68 \\
\hline Bauhinia sp. & & & & & 0.03 & \\
\hline Copaifera langsdorffii & 5.74 & 27.91 & 3.07 & 0.20 & 0.10 & 0.30 \\
\hline Leucaena sp. & & & 0.36 & 0.20 & 1.91 & \\
\hline Mimosa nuda & 6.57 & 8.51 & 14.10 & 0.10 & 0.11 & 0.30 \\
\hline Mimosa sp. & 0.09 & 0.25 & 0.45 & & & \\
\hline Stryphnodendron sp. & & & 0.18 & & 0.18 & \\
\hline Stylosanthes scabra & & & & & & 0.10 \\
\hline Trifolium sp. & & & 0.99 & 0.25 & 0.11 & \\
\hline Fabaceae unidentified 1 & & & & & 0.82 & \\
\hline Fabaceae unidentified 2 & 0.19 & 0.02 & & 0.10 & & \\
\hline \multicolumn{7}{|l|}{ Lamiaceae } \\
\hline Hyptis sp. & 0.02 & & 0.18 & 0.05 & & 0.30 \\
\hline \multicolumn{7}{|l|}{ Lecythidaceae } \\
\hline Cariniana sp. & & & & & 0.08 & 0.30 \\
\hline \multicolumn{7}{|l|}{ Loganiaceae } \\
\hline Antonia ovata & & & 0.63 & 0.30 & 0.05 & \\
\hline \multicolumn{7}{|l|}{ Loranthaceae } \\
\hline Struthanthus flexicaulis & & & 0.18 & 0.10 & 0.27 & 4.75 \\
\hline \multicolumn{7}{|l|}{ Malpighiaceae } \\
\hline Byrsonima coccolobifolia & & & & & 1.29 & 0.35 \\
\hline Byrsonima sp. & & & & & 0.78 & \\
\hline \multicolumn{7}{|l|}{ Melastomataceae } \\
\hline Melastomataceae unidentified 1 & & & & & 0.03 & \\
\hline \multicolumn{7}{|l|}{ Myrtaceae } \\
\hline Eucalyptus spp. & 7.81 & 8.65 & 20.61 & 4.98 & 9.87 & 6.37 \\
\hline Eugenia dysenterica & & & 0.18 & 1.96 & 0.80 & 0.30 \\
\hline Myrcia sp. DC. & 0.02 & 0.07 & 0.18 & & 5.00 & 1.01 \\
\hline Myrtaceae unidentified 1 & & & & & 0.10 & \\
\hline \multicolumn{7}{|l|}{ Onagraceae } \\
\hline Ludwigia sp. & & & & & 0.03 & \\
\hline \multicolumn{7}{|l|}{ Palmae } \\
\hline Palmae unidentified 1 & & & & & 0.04 & 0.05 \\
\hline \multicolumn{7}{|l|}{ Poaceae } \\
\hline Poaceae unidentified 1 & 6.35 & 11.35 & 3.62 & 0.35 & 0.03 & 1.16 \\
\hline \multicolumn{7}{|l|}{ Rubiaceae } \\
\hline Diodia sp. & 0.94 & 0.39 & 0.18 & 0.10 & & \\
\hline \multicolumn{7}{|l|}{ Sapindaceae } \\
\hline Serjania sp. & 0.02 & & 0.18 & 0.35 & 0.13 & \\
\hline \multicolumn{7}{|l|}{ Ulmaceae } \\
\hline Trema micranta & 29.94 & 4.45 & 4.25 & 2.52 & 3.65 & 8.49 \\
\hline
\end{tabular}

$\mathrm{N}=$ number of samples. 
Table 2. Continued...

\begin{tabular}{|c|c|c|c|c|c|c|}
\hline \multirow{3}{*}{ Pollen types } & \multicolumn{6}{|c|}{ Frequency of pollen types (\%) } \\
\hline & Jan/04 & Feb/04 & Aug/04 & Sep/04 & Nov/04 & Dec/04 \\
\hline & $N=4$ & $\mathbf{N}=4$ & $\mathbf{N}=\mathbf{2}$ & $\mathbf{N}=\mathbf{2}$ & $\mathbf{N}=7$ & $\mathbf{N}=\mathbf{2}$ \\
\hline \multicolumn{7}{|l|}{ Verbenaceae } \\
\hline Stachytarpheta sp. & 0.02 & & & & & \\
\hline \multicolumn{7}{|l|}{ Unidentified Families } \\
\hline Unidentified & 0.69 & 2.08 & 0.76 & 0.56 & 0.01 & 0.06 \\
\hline Total number of grains & 5404 & 4407 & 1106 & 1988 & 7920 & 1979 \\
\hline
\end{tabular}

$\mathrm{N}=$ number of samples.

\section{Discussion}

The pattern of resource exploitation observed in Fazenda Brejão is that of a generalist species, as observed previously by other authors for Apis mellifera (e. g. Ramalho et al., 1991; Viana et al., 1997; Strickler and Cane, 2003). However, in spite of the large amount of plant species visited, the honeybees concentrated their foraging activity in a few species, from which they gathered the largest amounts of pollen and nectar at given periods. This behavior of Apis mellifera has been previously described (e.g. Pedro and Camargo, 1991; Viana et al., 1997; Melo, 2004) and according to Lima (1995), it could be explained by the fact that the honeybee colonies concentrate their foraging activity in the most abundant flowering plants in any given time.

The fact that honeybees harvest a larger variety of pollen types during the dry season was already reported (e. g. Oliveira, 1998; Pedro and Camargo, 1991; Viana et al., 1997), and may be due to the low precipitation and air humidity, when honeybee foraging is favored (Szabo, 1980).

The occurrence of pollen grains of Myrtaceae and, especially, Eucalyptus spp. in the pollen samples of the honeybee and other bees is well known (Ramalho et al., 1991; Soares, 2003; Melo, 2004). This is because Eucalyptus produces massive amounts of flowers with large numbers of anthers, which produce large quantity of pollen, a characteristic of the plants most commonly visited by Apis mellifera (Moncur and Boland 1989; Ramalho et al., 1991).

Many species of the Asteraceae family common in antropic environments are frequent pollen sources for the honeybee and regarded as good bee plants (Bastos et al., 1995; Bastos et al., 1998).

Cecropia, a plant genus commonly considered to be anemophylous (Joly, 1979; Barth, 1989; Bastos et al., 1991; Bastos et al., 1993), was present as predominant pollen in September and December and as accessory pollen in January, February, August and November. Soares (2003) also observed large amounts of Cecropia pollen in honey samples of Melipona aff. rufiventris (Apidae, Meliponina) collected at Fazenda Brejão, especially during periods when food was most abundant for the bees. According to Barth (1989), pollen of anemophilous plants can be found in honey, sometimes in large amounts, as contaminants, but it is never used as a nectar source by bees. However, honeybees were observed visiting both male and female Cecropia inflorescences (personal observation) which is interesting because at least one Cecropia species is known to produce nectar (e. g. Andrade, 1984). An alternative explanation is that bees may be collecting honeydew produced by aphids commonly found on these plant's inflorescences. No analyses have been performed to verify whether the honey containing Cecropia pollen has the typical characteristics of honeydew.

An interesting finding was the relatively large amounts of the Trema micrantha pollen-types in the honey collected at Fazenda Brejão, contrasting with the small amounts generally encountered in other samples of Brazilian honey (Barth, 1989).

The frequent presence of Poaceae pollen found in the honey samples studied is probably a consequence of pollen from body bees, since plants of this family are not nectariferous (Barth, 1989) but bees are known to collect pollen from their flowers.

Our results indicate that although Eucalyptus is an important pollen and nectar source to honeybees, in bee yards established in areas of Eucalyptus plantations, nearby areas of native vegetation are also heavily exploited by the bees as floral resources.

\section{Acknowledgements}

We thank Vallourec \& Mannesmann Florestal for their logistic and financial support, Graça Leal for her help in the lab, Dr. Luiz Guilherme Heneine and Rânia Mara Santana for the contributions and to Conselho Nacional de Desenvolvimento Científico e Tecnológico (CNPq) for the M.S. scholarship granted to C. M. G. Simeão.

\section{References}

ANDRADE, J.C., 1984. Néctar em Cecropia lyratiloba Miq. Var. nana Andr. \& Car. (Cecropiaceae). Rodriguésia, vol. 36, pp. 81-84.

BARTH, O.M., 1970a. Análise microscópica de algumas amostras de mel. 1: pólen dominante. Anais da Academia Brasileira de Ciencias, vol. 42, pp. 51-366.

BARTH, O.M., 1970b. Análise microscópica de algumas amostras de mel. 1: pólen acessório. Anais da Academia Brasileira de Ciencias, vol. 42, pp. 571-590.

BARTH, O.M., 1970c. Análise microscópica de algumas amostras de mel. 1: pólen isolado. Anais da Academia Brasileira de Ciências, vol. 42, pp. 747-772. 
BARTH, O.M., 1989. O pólen no mel brasileiro. Rio de Janeiro: Luxor.

BASTOS, E.M., 1995. Espectro polínico do mel produzido em algumas áreas antrópicas de Minas Gerais. Brazilian Journal of Biology $=$ Revista Brasileira de Biologia, vol. 55, pp. 789-799.

BASTOS, E.M., 1996. Importância da caracterização dos grãos de pólen em produtos de origem apícola. In: Anais do $11^{\circ}$ Congresso Brasileiro de Apicultura, 26-30 November 1996, Teresina, Piauí. Teresina: Confederação Brasileira de Apicultura, pp. 225-228.

BASTOS, E.M., BRANDÃO, M. and DA SILVEIRA, F.R.C., 1995. Espectro dos méis produzidos no Parque Natural da Serra do Caraça-MG. Daphne, vol. 5, pp. 40-45.

BASTOS, E.M., BRANDÃO, M. and FERREIRA, J.A., 1993. Inventário da flora apícola de Bom Jesus do Amparo - Minas Gerais - II. Daphne, vol. 3, pp. 21-31

BASTOS, E.M., BRANDÃO, M., CASTELOIS, I.L. and SOARES, A.E.E., 1998. Inventário da flora apícola no estado de Minas Gerais: I - município de Cardeal Mota. Daphne, vol. 8, pp. 44-50.

BASTOS, E.M., GONÇALVES, T., BATISTA, E.B., BRANDÃO, M. and CASTELLOIS, B.C.R.J., 1991. Análise microscópica de amostras de mel do estado de Minas Gerais - I. Daphne, vol. 1, pp. 8-10.

BASTOS, E.M.A.F., SILVEIRA, V.M. and SOARES, A.E.E., 2003. Pollen spectrum of honey produced in cerrado areas os Minas Gerais State (Brazil). Brazilian Journal of Biology = Revista Brasileira de Biologia, vol. 63, no. 4, pp. 599-615. http:// dx.doi.org/10.1590/S1519-69842003000400007. PMid:15029371.

BERNARDO, A.L., REIS, M.G.F., REIS, G.G., HARRISON, R.B. and FIRME, D.J., 1998. Effect of spacing on growth and biomass distribution in Eucalyptus camaldulensis, E. pellita and E. urophylla plantations in southeastern Brazil. Forest Ecology and Management, vol. 104, no. 1-3, pp. 1-13. http://dx.doi. org/10.1016/S0378-1127(97)00199-0.

BRANDÃO, M., 2000. Cerrado. In: M.P. MENDONÇA and L.V. LINS. Lista vermelha das espécies ameaçadas de extinção da flora de Minas Gerais. Belo Horizonte: Fundação Biodiversitas, pp. 55-64.

CARVALHO, A.M.C. and BEGO, L., 1995. Seasonality of dominant species of bees in the Panga Ecological Reserve, cerrado, Uberlândia, MG. Anais da Sociedade Entomológica do Brasil, vol. 24, pp. 329-337.

CARVALHO, A.M.C. and BEGO, L., 1996. Studies on Apoidea fauna of cerrado vegetation at the Panga Ecological Reserve, Uberlândia, MG, Brazil. Revista Brasileira de Entomologia, vol. 40 , pp. 147-156.

DONER, L.W., 1977. The sugars of honey: a review. Journal of the Science of Food and Agriculture, vol. 28, no. 5, pp. 443456. http://dx.doi.org/10.1002/jsfa.2740280508. PMid:875373.

ERDTMAN, G., 1952. Pollen morphology and plant taxonomy: Angiosperms. Waltham: Chronica Botanica.

ERDTMAN, G., 1960. The Acetolyses method: a revised description. Svensk Botanisk Tidskrift, vol. 54, pp. 561-564.

GOLFARI, L., 1975. Zoneamento ecológico do estado de Minas Gerais para reflorestamento. Belo Horizonte: Centro de Pesquisa Florestal da Região do Cerrado.

GUERRA, A.G. and MÉNDEZ, R.B., 2004. Los Productos de la Colmena: buenas prácticas para su recolección, almacenamiento y conservación. Aplicaciones en la nutrición y salud del hombre. Cuba: Guerra and Méndez.

HOWES, F.N., 1953. Plantas meliferas. Barcelona: Reverté.

JOLY, A.B., 1979. Botânica: introdução à taxonomia vegetal. São Paulo: Nacional.

LABORIAU, M.L.S., 1973. Contribuição à palinologia dos cerrados. Rio de Janeiro: Academia Brasileira de Ciências.

LIMA, A.O.N., 1995. Pólen coletado por abelhas africanizadas em apiário comercial na caating a cearense. Fortaleza: Universidade Federal do Ceará, 18 p. Master's Dissertation in Zootechnics.

LOUVEAUX, J., MAURIZIO, A. and VORWOHL, G., 1970. Methods of melissopalinology. Bee World, vol. 51, no. 3, pp. 125-138. http://dx.doi.org/10.1080/0005772X.1970.11097312.

LOUVEAUX, J., MAURIZIO, A. and VORWOHL, G., 1978. Methods os melissopalinogy. Bee World, vol. 4, no. 4, pp. 139-157. http://dx.doi.org/10.1080/0005772X.1978.11097714.

MELO, M.A., 2004. Efeito de Apis mellifera Linnaeus, 1758 (Hymenoptera, Apidae) sobre a utilização de fontes de pólen por Melipona quadrifasciata Lepeletier, 1836 (Hymenoptera, Apidae) na região de Viçosa, $M G$. Viçosa: Universidade Federal de Viçosa, 59 f. Doctoral Thesis in Entomology.

MINCKLEY, R.L., CANE, J.H. and KERVIN, L., 2000. Origins and ecological consequences of pollen specialization among desert bees. Proceedings of the Royal Society B: Bilogical Sciences, vol. 267, pp. 265-271.

MITTERMEIER, R.A., MYERS, N. and MITTERMEIER, C.G., 2000. Hotspots: earth's biologically richest and most endangered terrestrial ecoregions. Mexico City: CEMEX.

MONCUR, M.W. and BOLAND, D.J., 1989. Floral morphology of Eucalyptus melliodora A. Cunn. ex Schau. and comparisons with other eucalypt species. Australian Journal of Botany, vol. 37, no. 2, pp. 125-135. http://dx.doi.org/10.1071/BT9890125.

MORETI, A.C.C.C., CARVALHO, A.L., MARCHINI, L.C. and OLIVEIRA, P.C.F., 2000. Espectro polínico de amostras de mel de Apis mellifera L., coletadas na Bahia. Bragantia, vol. 59, no. 1, pp. 1-6. http://dx.doi.org/10.1590/S0006-87052000000100002.

NAGAMITSU, T. and INOUE, T., 1999. Differences in pollen sources of Apis cerana and Apis mellifera at a primary beech forest in central Japan. Journal of Apicultural Research, vol. 38, pp. 71-78.

OLIVEIRA, P.E., 1998. Fenologia e biologia reprodutiva das espécies de cerrado. In: S.M. SANO and S.P. ALMEIDA. Cerrado: environment and flora. Planaltina: EMBRAPA-CPAC, pp. 169-192.

PEDRO, S.R.M. and CAMARGO, J.M.F., 1991. Interactions on floral resources between the africanized honey bee Apis mellifera $\mathrm{L}$ and the native bee community (Hymenoptera: Apoidea) in a natural "cerrado" ecosystem in southeast Brazil. Apidologie, vol. 22, no. 4, pp. 397-415. http://dx.doi.org/10.1051/apido:19910405.

RAMALHO, M., GUIBU, L.S., GIANNINI, T.C., KLEINERTGIOVANNINI, A. and IMPERATRIZ-FONSECA, V.L., 1991. Characterization of some southern Brazilian honey and bee plants through pollen analysis. Journal of Apicultural Research, vol. 30 , pp. 81-86.

SCOLFORO, J.R.S., MELLO, J.M., ACERBI, J.R.F.W., OLIVEIRA, A.D., BORGES, L.F.R. and OLIVEIRA, L.T., 2001. Diagnóstico e proposta de manejo de fragmentos florestais nativos, na Vallourec \& Mannesmann Florestal, região de Brasilândia de Minas, Minas Gerais. Lavras: Universidade de Lavras. 
SILVA, J.M. and BATES, J.M., 2002. Biogeographic patterns and conservation in the South American cerrado: a tropical savanna hotspot. Bioscience, vol. 52, no. 3, pp. 225-233. http://dx.doi. org/10.1641/0006-3568(2002)052[0225:BPACIT]2.0.CO;2.

SILVEIRA, C., 2004. Manejo do eucalipto exige cuidado. Jornal Manuelzão, vol. 28, pp. 7.

SOARES, S.M., 2003. Utilização de recursos alimentares por Melipona rufiventris (Apidae, Meliponina) no cerrado de Brasilândia de Minas, MG. Belo Horizonte: Universidade Federal de Minas Gerais, 95 p. Master's Dissertation in in Ecology and Wildlife Conservation and Management.
STRICKLER, K. and CANE, J.H., 2003. For nonnative crops, whence pollinators of the future? Lanham: Entomological Society of America.

SZABO, T.I., 1980. Effect of weather factors on honey-bee flight activity and colony weight-gain. Journal of Apicultural Research, vol. 19 , pp. 164-171.

VIANA, B.F., KLEINERT, A.M.P. and IMPERATRIZ-FONSECA, V.L., 1997. Abundance and flower visits of bees in a cerrado of Bahia, Tropical Brazil. Studies on Neotropical Fauna and Environment, vol. 32, no. 4, pp. 212-219. http://dx.doi.org/10.1 080/01650521.1997.11432424. 